\title{
PERSEPSI AKUNTAN PUBLIK PEMAKAI INFORMASI DAN MAHASISWA AKUNTANSI TERHADAP ADVERTENSI KANTOR AKUNTAN PUBLIK
}

\author{
Oleh :
}

Kesit Bambang Prakosa *)

\section{ABSTRAK}

Terbitnya Kode Etik Profesi No. 502 tahun 2000, telah mengubah secara mendasar bagi kantor akuntan publik (KAP). Isi dari KEP ini memperkenankan KAP untuk beradventernsi. Kebijakan baru IAI di bidang advertensi bagi KAP ini, ter-nyata menimbulkan tanggapan yang berbeda dikalangan masyarakat akuntansi, ada yang positif(pro) dan ada pula yang negatif(kontra).Tujuan penelitian ini untuk mengetahui apakah akuntan publik, pemakai informasi akuntansi, dan mahasiswa akuntansi baik sebagai satu kalompok tergabung maupun sebagai kelompok terpisah memiliki persepsi positif terhadap advertensi kantor akuntan publik(KAP). Hasil penelitian membuktikan bahwa akuntan publik, pemakai informasi akuntansi, dan mahasiswa akuntansi baik sebagai satu kalompok tergabung maupun sebagai kelompok terpisah memiliki persepsi positifterhadap advertensi kantor akuntan publik(KAP). Artinya, baik akuntan publik, pemakai informasi akuntansi, maupun mahasiswa akuntansi secara empirik terbukti mendukung terhadap Kode Etik Profesi: Aturan Etika No. 502 tentang advertensi bagi KAP yang telah sahkan oleh IAI.

Key words: Advertensi, Kantor Akuntan Publik, dan Kode Etik Profesi:Aturan Etika No.502

\section{A. PENDAhUluan}

Akuntan, suatu profesi yang menyediakan jasa di bidang akuntansi dan auditing untuk masyarakat: Keberlangsungan profesi akuntan sangat bergantung pada tingkat kepercayaan masyarakat yang dilayaninya. Untuk menjaga kepercayaan masyarakat terhadap profesi akuntan, maka diperiukan standar perilaku keprofesian yang dikenal dengan kode etik. Kode etik ini disusun oleh organisasi profesi dalam hal ini, Ikatan Akuntan Indonesia (IAI).

Kode etik profesi merupakan standar perilaku yang bertujuan untuk menjaga kepercayaan masyarakat dalam menggunakan jasa terhadap suatu profesi. Hal ini juga berlaku bagi profesi Akuntan. Keberlangsungan profesi akuntan sangat bergantung pada tingkat kepercayaan dari masyarakat yang dilayaninya. Kepercayaan masyarakat dapat terjaga jika akuntan mematuhi kode etik profesinya sebagai wujud kontra prestasi bagi masyarakat penggunanya..

Kode Etik Akuntan Indonesia diatur dengan Kode Etik Profesi (KEP) Nomor 4 tahun 1994. Isi KEP No.4 tahun 1994 ini, menyebutkan larangan bagi akuntan publik mengiklankan diri atau mengijinkan orang lain untuk mengiklankan nama

\footnotetext{
") Kesit Bambang Prakosa, SE, M.Si adalạh Dosen Tetap Fakultas Ekonomi Universitas Islam Indonesia (UII)
} 
Kesit Bambang Prakosa, Persepsi Akuntan Publik, Pemakai Informasi Dan Mahasiswa ....

atau jasa yang diberikannya kecuali yang sifatnya pemberitahuan serta tidak diperkenankan menawarkan jasanya secara tertulis kepada calon klien atas permintaan calon klien. Namun, dalam perkembangannya di tahun 2000 , IAl menerbitkan KEP Nomor 502 tahun 2000, untuk menggantikan KEP No. 4 Tahun 1994. Dalam KEP Nomor 502 tahun 2000 terjadi perubahan yang mendasar dalam hal advertensi bagi akuntan publik. Pada KEP No.4 Tahun 1994 dilarang tetapi KEP No.502 Tahun 2000 diperbolehkan. Kebijakan baru IAI di bidang advertensi bagi KAP ini, ternyata menimbulkan tanggapan yang berbeda dikalangan masyarakat akuntansi, ada yang positif (pro) dan ada pula yang negatif (kontra). Keadaan demikian inilah menarik untuk diteliti.

Tujuan dan manfaat yang ingin dicapai dalam penelitian adalah untuk mengetahui apakah akuntan publik, pemakai informasi akuntansi dan mahasiswa akuntansi baik sebagai satu kelompok tergabung maupun sebagai kelompok terpisah memiliki persepsi yang positif terhadap advertensi Kantor Akuntan Publik. Selain itu, untuk membuktikan secara empiris apakah akuntan publik, pemakai informasi akuntansi dan mahasiswa akuntansi baik sebagai satu kelompok maupun secara terpisah mendukung' Kode Etik Profesi: 'Aturan. Etika No.502 Tahun 2000 yang berisi diperbolehkannya KAP beradvertensi. Dengan demikian, rumusan masalah dalam penelitian ini adalah (1) Apakah akuntan publik, pemakai informasi akuntansi dan mahasiswa akuntansi secara bersama-sama memiliki persepsi yang positif terhadap advertensi Kantor Akuntan Publik dan (2) Apakah akuntan publik, pemakai informa-si akuntansi dan mahasiswa akuntansi secara terpisah memiliki persepsi yang positif terhadap advertensi Kantor Akuntan Publik.

\section{B. KERANGKA TEORI}

\section{Pengertian Persepsi}

Persepsi, menurut Rakhmat Jalaludin (1998: 51), adalah|pengalaman tentang objek, peristiwa, atau hubungan-hubungan yang diperoleh dengan menyimpulkan informasi dan menafsirkan pesan. Menurut Ruch (1967: 300), persepsi adalah suatu proses tentang petunjuk-petunjuk inderawi (sensory) dan pengalaman masa lampau yang relevan diorganisasikan untuk memberikan kepada seseorang gambaran yang terstruktur dan bermakna pada suatu situasi tertentu. Senada dengan hal tersebut Atkinson dan Hilgard (1991: 201) mengemukakan bahwa persepsi adalah proses dimana seseorangan menafsirkan dan mengorganisasikan pola stimulus dalam lingkungan. Gibson dan Donely (1994: 53) menjelaskan bahwa persepsi adalah proses pemberian arti terhadap lingkungan oleh seorang individu.

Dikarenakan persepsi bertautan dengan cara mendapatkan pengetahuan khusus tentang kejadian pada saat tertentu, maka persepsi terjadi kapan saja stimulus menggerakkan indera. Pada konteks ini persepsi diartikan sebagai proses mengetahui atau mengenali obyek dan kejadian obyektif dengan bantuan indera (Chaplin, 1989: 358). Sebagai cara pandang, persepsi timbul karena adanya respon terhadap stimulus. Stimulus yang diterima seseorang sangat komplek, stimulus masuk ke dalam otak, kernudian diartikan, ditafsirkán serta diberi makna melalui proses yang rumit baru kemudian menghasilkan persepsi (Atkinsón dan Hilgard, 1991 : 209). Dalam hal ini, persepsi mencakup penerimaan stimulus 
(inputs), pengorganisasian stimulus dan penerjemahan atau penafsiran stimulus yang telah diorganisasi dengan cara yang dapat mempengaruhi perilaku dan membentuk sikap, sehingga orang dapaț cenderung menafsirkan perilaku orang lain sesuai dengan keadaannya sendiri (Gibson, 1986: 54).

\section{Pembentukan Persepsi dan Faktor-Faktor yang Menpengaruhi}

Proses pembentukan persepsi dijelaskan oleh Feigi (daiam Yusuf, 1991: 108) sebagai pemaknaan hasil pengamatan yang diawali dengan adanya stimuli. Setelah mendapat stimuli, pada tahap selanjutnya terjadi seleksi yang berinteraksi dengan "interpretation", begitu juga berinteraksi dengan "closure". Proses seleksi terjadi pada saat seseorang memperoleh informasi, maka akan berlangsung proses penyeleksian pesan tentang mana pesan yang dianggap penting dan tidak penting. Proses closure terjadi ketika hasil seleksi tersebut akan disusun menjadi satu kesatuan yang berurutan dan bermakna, sedangkan interpretasi berlangsung ketika yang bersangkutan memberi tafsiran atau makna terhadap informasi tersebut secara menyeluruh. Menurut Asngari (1984: 12-13) pada fase interpretasi ini, pengalaman masa silam atau dahulu, memegang peranan yang penting. Faktor-faktor fungsional yang menentukan persepsi seseorang berasal dari kebutuhan, pengalaman masa lalu dan hai-hal lain termasuk yang kita sebut sebagai faktor-faktor personal (Rakhmat 1998: 55). Selaras dengan pernyataan tersebut Krech, dkk. (dalam Sri Tjahjorini Sugiharto 2001: 19) mengemukakan bahwa persepsi seseorang ditentukan oleh dua faktor utama, yakni pengalaman masa lalu dan faktor pribadi. Selanjutnya Rakhmat menjelaskan yang menentukan persepsi bukan jenis atau bentuk stimuli, tetapi karakteristik orang yang memberi respon terhadap stimuli. Dengan demikian, persepsi meliputi juga kognisi (pengetahuan), yang mencakup penafsiran objek, tanda dan orang dari sudut pengalaman yang bersangkutan (Gibson, 1986:54).

\section{Kode Etik Advertensi Kantor Akuntan Publik bagi Profesi Akuntan}

Kode etik merupakan prinsip moral yang mengatur perilaku anggota profesi yang ditetapkan dengan tujuan melindungi kepentingan anggota profesi dan masyarakat yang memanfaatkan jasa profesi sebagai prinsip moral maka kode etik profesi menjadi pedoman bagi anggota profesi dan masyarakat umum. Anggota profesi wajib mematuhi ketentuan-ketentuan yang terdapat di kode etik profesi dalam memberikan pelayanan jasa profesi.

Ikatan Akuntan Indonesia (IAI) sebagai organisasi profesi menetapkan Kode Etik Akuntan Indonesia sebagai standar perilaku untuk mengatur perilaku anggotanya dalam menjalankan praktik profesinya. Kode etik tersebut ditetapkan sebagai bentuk rasa tanggung jawab organisasi profesi kepada pemakai jasa akuntan publik. Selaras dengan perkembangan dan kebutuhan IAI melakukan perubahan kode etik, perubahan ini dilakukan sebagai konsekuensi sifat dinamis suatu kode etik profesi.

Sebeium tahun 2000 , akuntan publik dilarang mengiklankan jasanya atau melakukan kegiatan advertensi, hal ini diatur dalam Pernyataan Etika Profesi Nomor 4 tahun 1994. Namun, pernyataan tersebut direvisi dengan menetapkan Aturan Etika Nomor 502 tahun 2000 yang meperbolehkan akuntan publik melakukan advertensi. Ketentuan ini menegaskan bahwa anggota dalam 
Kesit Bambang Prakosa, Persepsi Akuntan Publik, Pemakai Informasi Dan Mahasiswa ....

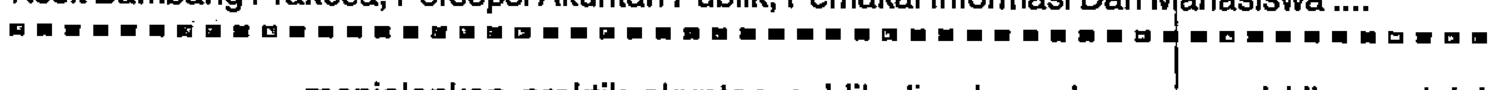

menjalankan praktik akuntan publik diperkenankan mencari klien melalui pemasangan iklan, melakukan promosi pemasaran dan kegiatan pemasaran lainnya sepanjang tidak merendahkan citra profesi. Artinya, isi advertensi tidak mengandung informasi yang bersifat paisu, menyesatkan, menipu, memaksa, berlebihan atau pelecehan (Interpretasi Aturan Etika No. 502, IAI, 2001).

\section{Penelitian Persepsi terhadap Adverterisi KAP}

Penelitian tentang sikap atau persepsi terhadap advetensi jasa akuntan di Indonesia telah dilakukan oleh Ambarriani (1996), Prabowo (1998), Lay (1999), Husnul Khotimah (2000), Yunita (2000), dan Yohanes Suhardjo (2000), serta Nasyiah dan Payamta (2002) menghasilkan adanya sikap positif terhadap advertensi akuntan publik. Faktor-faktor deteminan yang mempengaruhi persepsi advertensi KAP yang digunakan penelitian ini merujuk pada instrument penelitian Yohanes Suhardjo (2000) meliputi materi advertensi, manfaat advertensi bagi klien, manfaat advertensi bagi KAP, manfaat advertensi bagi pemakai informasi akuntansi, manfaat advertensi bagi profesi dan manfaat media advertensi. Dari kerangka teori tersebut, maka dirumuskan hipotesis penelitan sebagai berikut:

1.Akuntan publik, pemakai informasi akuntansi dan mahasiswa akuntansi secara serentak memiliki persepsi yang positif terhadap advertensi KAP

2.Akuntan publik, pemakai informasi akuntansi dan mahasiswa akuntansi secara terpisah masing-masing memiliki persepsi yang positif terhadap advertensi KAP

\section{METODOLOGI PENELITIAN}

\section{Populasi dan Sampel}

Populasi yangjadi responden penelitian inimeliputiakuntan publik, pemakai informasi akuntansi, mahasiswa akuntansi pada Perguruan Tinggi Negri (PTN) dan Pergunuan Tinggi Swasta (PTS) di Jakarta. Sample yang diambil dalam penelitian ini ada 90 responden. Teknik pengambilan sampelnya menggunakan judgment sampling, yaitu teknik pengambilan sampling yang mendasarkan pada pertimbangan kriteria-kriteria tertentu kelompok responden, yaitu:

1. Kelompok akuntan publik diwakili oleh auditor yang berpendidikan $S 1$ jurusan akuntansi dan berpraktek di KAP serta bukan auditor magang.

2. Kelompok pemakai informasi akuntansi diwakili oleh manajer perbankan atau posisi yang setingkat.

3. Kelompok mahasiswa akuntansi diwakili oleh mahasiswa program $\mathrm{S} 1$ jurusan akuntansi yang telah menempuh mata kuliah auditingl.

\section{. Pengukuran dan Pengujian Variabel}

Pengukuran variable penelitian ini yang menggunakan skala likert yang terbagi ke dalam 5 kategori yaitu sangat tidak setuju (1), tidak setuju (2), netral (3), setuju (4) dan sangat setuju (5). Pengujian validitas instrument dilakukan dengan menggunakan teknik person correlation. Sedangkan Pengujian reliabilitas dalam penelitian ini memakai pendekatan konsistensi intemal yaitu dengan menggunakan metode belah dua (Spilt- : Half) untukmenghitung Spearman-Brown Correlation Coefficient. 


\section{Pengujian Hipotesis}

Sebelum uji hipotesis dilakukan, maka dilakukan terlebih dahulu uji asumsi normalitas menggunakan Kolmogorov-Smirnov (K-S). Jika signifikasinya lebih besar dari 0.05 maka data berdistribusi normal. Pengujian asumsi homogenitas menggunakan Uji Lavene Test. Jika signifikasinya lebih besar dari 0.05 maka varian bersifat homogen. Pengujian hipotesis dilakukan menggunakan mean populasi yaitu menguji perbedaan mean populasi terhadap mean yang dihipotesiskan dan alat statistik yang digunakan adalah uji one sample t-test.

\section{HASIL DAN PEMBAHASAN PENELITIAN}

\section{Pengujian Validitas dan Reliabilitas}

Pengujian validitas menggunakan Pearson Corelatioan menighasilkan 30 (tiga puluh) item pernyataan menghasilkan nilai koefisien korelasi pearson positif dan signifikan $(0.000)$, sedangkan pengujian realibilitas menggunakan korelasi Spearman-Brown menghasilkan koefisien korelasi Spearman-Brown yang lebih besar dari $r$ tabel (0.20718). Dengan demikian ke 30 (ketigapuluh) pertanyaan tersebut valid dan reliabel.

\section{Pengujian Normalitas dan Homogenitas}

Pengujian normalitas Kolmogorov-Smirnovm test menunjukan tiga kelompok responden terdistribusi normal diatas $0.05(0,334-0,920)$. Pengujian homogenitas varian uji Levene Test menunjukan signifikasinya sebesar 0.139 di atas $=0.05$ berarti data memiliki varian yang sama atau homogen. Berdasarkan pada pengujian normalitas dan homogenitas data, maka dilakukan pengujian dengan one-sampel t test, dengan hasil sebagai berikut :

Tabel 2. Hasil Pengujian Hipotesis

\begin{tabular}{|c|c|c|c|c|}
\hline Uji Signifikasi & Hipotesis & Nilai t & Mean Deference & p-value \\
\hline & $\mathrm{H} 1$ & 24.268 & 29.4222 & 0.000 \\
& $\mathrm{H}_{2 \mathrm{a}}$ & 24.813 & 26.4333 & 0.000 \\
One-sample t test: & $\mathrm{H}_{2 \mathrm{~b}}$ & 11.221 & 28.8333 & 0.000 \\
& $\mathrm{H}_{2 \mathrm{c}}$ & 14.707 & 33.0000 & 0.000 \\
\hline
\end{tabular}

Sumber : hasil olahan, 2004

Dari pengujian one-sampel test tersebut, menunjukan bahwa akuntan publik, pemakai informasi akuntansi dan mahasiswa akuntansi secara bersama-sama (serentak) memiliki persepsi yang positif terhadap advertensi kantor akuntan publik (KAP), hal ini tampak pada hasil pengujian hipotesis 1 menunjukkan $t$ hitung (24.268) lebih besar darit tabel $(1.6622,=5 \%$; $d f=89$ ), $p$ value signifikan $(0.000)$. Demikian pula, dari hasil pengujian secara parsial menunjukkan akuntan publik (nilai $t$ hitung $=24.813$ ), pemakai informasi akuntansi (nilai $t$ hitung $=$ 
11.221) dan mahasiswa akuntansi (nilai thitung=14.707) sebagai masing-masing kelompok terpisah memiliki persepsi positif terhadap adyertensi KAP. Hal ini terbukti nilai untuk $\mathrm{t}$ hitung ketiga variabel tersebut di atas $\mathrm{t}$ tabel $(1.6991,=$ $5 \%$; $d \mathrm{f}=29$ ), sehingga signifikan.

Hasil penelitian ini menunjukkan bahwa akuntan publik, pemakai informasi akuntansi dan mahasiswa akuntansi baik secara kelompok maupun secara terpisah memiliki persepsi positif terhadap advertensi KAP.|Artinya, para praktisi dibidang akuntansi menganggap sudah waktunya praktik akuntan sebagai sebuah profesi melakukan advertensi sebagai salah satu sistem marketingnya. Hasil penelitian ini lebih memperkuat hasil penelitian terdahulu (Prabowo (1998), Lay (1999), Husnul Khotimah, Yunita dan Yohanes Suhardjo, 2000). Anggapan bahwa akuntan tabu dalam menawarkan jasanya kepada masyarakat sudah saatnya diubah karena sudah tidak sesuai lagi dengan keadaan dan kondisi pada saat ini. Advertensi bagi KAP bukan sekedar untuk mencari calon klien tetapi lebih merupakan media informasi kepada masyarakat tentang jasa layanan yang dapat diberikan oleh KAP.

Tidak ada jaminan jika tidak advertensi akan meninggikan citra profesionalisme KAP. Sebelum tahun 1996, banyak persepsi akuntan yang mengatakan advertensi itu tidak perlu dilakukan oleh KAP dan ini sesuai dengan hasil penelitian Ambarriani (1996), yang menghasilkan bahwa persepsi akuntan publik terhadap advertensi kantor akuntan publik adalah tidak positif, artinya akuntan publik menganggap tidak perlu adanya advertensi bagi KAP, yang mana pada saat itu masih berlakunya kode etik terhadap pelarangan advertensi bagi praktik akuntan publik. Namun setelah tahun 1996, dari hasil beberapa penelitian menunjukkan adanya kecenderungain perubahan sikap para akuntan untuk menerima KAP perlu beradvertensi. Perubahan sikap ini tidak teriepas dari pengaruh globalisasi internasional dan perubahan sikap para akuntan di USA yang telah menerima advertensi sebagai salah satu model marketing bagi KAP, Apalagi selama ini keadaan dan perubahan di lingkungan akuntan USA menjadi kiblat para akuntan Indonesia.

Pada sisi lain, sikap kekhawatiran sebagian praktisi tentang ternodanya citra profesi akuntan di mata para pemakai jasa akuntan publik jika melakukan advertensi dengan sendirinya akan terbantah. Hal ini ditunjukkan pada penelitian ini manager perbankan sebagai pemakai informasi yang dihasilkan dari jasa akuntan publik, mendukung adanya advertensi KAP. Demikian pula, yang patut dipertimbangkan pendapat mahasiswa akuntansi sebagai wakil calon auditor juga tidak memberikan respon yang menentang terhadap advertensi KAP.

Kode etik nomor 502 tahn 2000 tentang diperbolehkannya KAP beriklan pada kenyataannya tidak terlalu ditanggapi secara antusias oleh para akuntan publik dengan bukti sedikit sekali ditemukannya iklan sebuah KAP. Bukti-bukti empiris seperti yang dihasilkan dari penelitian ini sangat diperlukan untuk menyamakan persepsi agar pro kontra yang terjadi dalam menyikapi masalah ini tidak berlarutlarut. Bukti empiris ini juga diharapkan dapat membantu|menyakinkan para praktisi bahwa melakukan advertensi tidak akan merusak citra profesi akuntan jika dilakukan sesuai dengan ketetapan yang digariskan oleh IAI-KAP melalui Interpretasi Aturan Etika nomor 502. 


\section{Simpulan}

Penelitian ini membuktikan bahwa akuntan publik, pemakai informasi akuntansi, dan mahasiswa akuntansi baik sebagai satu kalompok tergabung maupun sebagai kelompok terpisah memiliki persepsi positif terhadap advertensi kantor akuntan publik. Dengan kata lain mereka mendukung kode etik nomor 502 tahn 2000 tentang diperbolehkannya KAP beriklan. Hasil penelitian ini memberikan bukti empiris dukungan terhadap Kode Etik: Aturan Etika No. 502 tentang adveirtensi bagi kantor akuntan publik yang telah sahkan oleh IAI.

\section{Keterbatasan Penelitian}

Keterbatasan penelitian ini, lingkup wilayah penelitian ini hanya mencakup wilayah Jakarta sehingga generalisasi hasil penelitian belum dapat dilakukan. Selain itu, penentuan responden kelompok pemakai informasi akuntansi baru terbatas pada manager perbankan saja, hal ini dimungkinkan mepengaruhi validitas dàta kelompok responden tersebut. Demikian pula untuk kelompok mahasiswa yang direpresentasikan sebagai wakil akademisi, hal ini dimungkinkan karena jika diwakilkan dosen dikhawatirkan bias (biasanya dosen akuntansi juga merupakan auditor partnership di KAP). 
Keșit Bambang Prakosa, Persepsi Akuntan Publik, Pemakai Informasi Dan Mahasiswa ...

DAFTAR PUSTAKA

,2001, Konsep Iklan KAP, Media Akuntansi, No, 17, april-Mei.

Allen, Paul A, dan Danny R. Arnold, 1991, How To Develope An Advertising Program for An Accounting Practice, The CPA Journal, Ha: $32-35$.

Ambarriani, Susty, 1996, Persepsi Akuntan Terhadap Promosi dan Advertensi Aukntan Publik, Tesis S-2 UGM, Yogyakarta.

Gibson, Ivancevich, dan Donelly (terj.), 1996, Organisasi, Perilaku, Struktur, Proses, edisi kedelapan, Binarupa Aksara, Jakarta.

Halim, Abdul, 1997, Auditing 1 (Dasar-dasar Audit Laporan Keuangan), UUP AMP YKPN, Yogyakarta.

Ikatan Akuntan Indoneșia, 2001; Interpretasi Aturan Etika Nomor 502, Jakarta.

Iskak, Jamaludin, 2000, Larangan Iklan dalam Aturan Etika Profesi, Media Akuntansi, No. 11 Th.VII/Juli, Hal 8-11.

Mulyadi, 2002, Auditing (buku 1), Salemba Empat, Jakarta.

Nasyiah, HP dan Payamta, Sikap Akuntan Terhadap Advertensi Jasa Akuntan Publik, JAAI, Vol 6, Juni 2002.

Payamta dan Zamaluddin, 1997, Akuntan sebagai Profesi Etis, Perspektif, April-Juni.

Payamta, 2002, Sikap Akuntan dan Pengguna Jasa Akuntan Publik terhadap Advertenși Jasa Akuntan Publik, Simposium Nasional Akuntansi.

Prabowo, Tommy, 2001, Akuntan Beriklan, Efektifkah?, Media Akuntansi, No. 17, april-Mei, Hal 44.

Rakhmat, Jalaluddin, (1998), Psikologi Komunikasi, PT. ROSDAKARYA, Bandung

Sihwahjoeni dan M. Gudono, 2000; Persepsi Akuntan terhadap Kode Etik Akuntan, Jurnal Riset Akuntansi Indonesia, Vol. 3, No. 2, Juli

Suhardjo, Yohanes dan Mardiasmo, Persepsi Akuntan Publik, Pemakai Informasi Akuntansi Dan Mahasiswa Akuntansi Terhadap Advertensi Kantor Akuntan Publik Pada Eks Karasidenan Semarang, Kompak, No. 4, Januari 2002, Hal.1-13. 